\title{
Elazığ Koşullarına Uygun Kuru Fasulye Çeşitlerinin Araştırılması
}

\author{
Leyla İDIKUT ${ }^{1}$, Tolga KARABACAK ${ }^{2}$ \\ ${ }^{1}$ K.S.Ü. Ziraat Fakültesi, Tarla Bitkileri Bölümü, Kahramanmaraş, ${ }^{2}$ Elazı̆̆ Tarım Kredi Kooperatifi, Elazığ \\ ${ }^{1}$ https://orcid.org/0000-0002-0685-7158, ${ }^{2}$ https://orcid.org/0000-0003-4406-5001 \\ $\square$ : leylaidikut@gmail.com
}

\begin{abstract}
ÖZET
Elazığ ekolojisine uygun fasulye çeşitlerinin belirlemek amacıyla, Önceler 98, Göynük 98, Yunus 90, Topçu, Aras 98, Alberto, Bermaz, Noyanbey 98, Akman 98, Göksün, Karacaşehir 98 çeşitleri ElazığMaden ilçesi koşullarında 2017 fasulye yetiştirme sezonunda denenmiştir. Deneme tesadüf blokları deneme deseninde 4 tekrarlamalı, $50 \mathrm{~cm}$ sira arası ve $10 \mathrm{~cm}$ üzeri mesafesinde kurulmuştur. Araştırmada çeşitlerinin çiçeklenme süresi, bakla bağlama süresi, bitki boyu, bakla yüksekliği, bakla sayısı, dolu bakla sayısı, olgunluk süresi ve tane verim değerleri incelenmiştir. Araştırma sonuçlarına göre çiçeklenme sürelerinin 53.0 - 60.0 gün, bakla bağlama sürelerinin 77.0-91.00 gün, bitki boylarının 33.2-62.4 $\mathrm{cm}$, bakla yüksekliğinin $12.9-27.05 \mathrm{~cm}$, bakla sayısının $17.15-43.60$ adet, dolu bakla sayısının 16.57-43.40 adet, tane verimi 141.43-333.10 $\mathrm{kg} / \mathrm{da}$ arasında saptanmıştır. Tane veriminin $318 \mathrm{~kg} \mathrm{da}^{-1}$ yüksek, bakla bağlama süresi 77-82 gün arasında ve olgunlaşma süresi 115 gün olan Önceler 98, Göynük 98, Yunus 90, Aras 98 çeşitlerin Elazığ yöresi için uygun olduğu sonucuna varılmıştır.
\end{abstract}

\section{The Research of Suitable Dry Beans Varieties for Elazig Conditions}

\begin{abstract}
In order to determine the suitable bean varieties for Elazig ecology, Önceler 98, Göynük 98, Yunus 90, Topçu, Aras 98, Alberto, Bermaz, Noyanbey 98, Akman 98, Göksün, and Karacaşehir 98 varieties were grown in Maden district of Elazığ, in 2017. The trial was designed as a random blocks design as 4 replicates with $50 \mathrm{~cm}$ inter row and 10 $\mathrm{cm}$ intra row density. The flowering period, seed set period, plant height, pod height, pod number, filled pod number, ripening period and grain yield of the varieties were determined. The investigated characters were ranged 53.0 - 60.0 days for flowering times, 77.0-91.00 days for seed set time, $33.2-62.4 \mathrm{~cm}$ for plant height, $12.9-27.05 \mathrm{~cm}$ for height of pods, 17.15 -43.60 for number of pods, 16.57-43.40 for number of filled pods, $115.00-16.25$ days for maturity period and 141.43-333.10 $\mathrm{kg} \mathrm{da}{ }^{-1}$ for grain yield. It was concluded that Önceler 98, Göynük 98, Yunus 90, Aras 98 varieties which had $318 \mathrm{~kg}$ da-1 higher grain yield, 77-82 days bean seet setting time and 115 days ripening period were suitable for Elazığ region.
\end{abstract}

Araştırma Makalesi

$\begin{array}{ll}\text { Makale Tarihçesi } \\ \text { Geliş Tarihi } & : 22.04 .2020 \\ \text { Kabul Tarihi } & : 04.07 .2020\end{array}$

Anahtar Kelimeler

Kuru fasulye

Çeşit

Verim
Research Article

$\begin{array}{ll}\text { Article History } & \\ \text { Received } & : 22.04 .2020 \\ \text { Accepted } & : 04.07 .2020\end{array}$

Keywords

Dry beans

Cultivars

Yield

\begin{tabular}{ll}
\hline To Cite: & İdikut L, Karabacak T 2021. Elazı̆̆ Koşullarına Uygun Kuru Fasulye Çeşitlerinin Araştırılması. KSÜ Tarım ve \\
& Doğa Derg 24 (2): 299-305. https://doi.org/10.18016/ksutarimdoga.vi.725109. \\
To Cite: & İdikut L, Karabacak T 2021. The Research of Suitable Dry Beans Varieties for Elazıg Conditions. KSU J. Agric \\
& Nat 24 (2): 299-305. https://doi.org/10.18016/ksutarimdoga.vi.725109. \\
\hline
\end{tabular}

\section{GİİŞ}

Dünya'da ve Türkiye'de yaygın olarak yetiştirilen fasulye önemli bir tarım ürünüdür. Fasulye protein yönünden zengin olması nedeniyle tüketimine talebi de fazladir. Fasulye bitkisi ; taze fasulye, konserve ve kuru tane olarak ticareti yapılmakta ve insanların kullanımına sunulmaktadır. Ayrıca başta Türkiye olmak üzere birçok ülke mutfağının temel ürünlerinden olduğu için üretimi de önemlilik arz etmektedir.

Fasulye baklagiller grubunda yer alan bir bitkidir. İklim koşullarının uygun olması halinde çimlenmesini tamamlayıp, toprak yüzeyine çıkan her bitki gibi, fasulye bitkisi de gelişmesini sürdürmek için topraktan suyla birlikte besin almaktadır. Baklagiller bitkileri topraktan besin alırken gelişmesini 
sürdürürken, nodozitelerini oluşturarak havanın serbest azotunu köklerine bağlayarak hem kendi için gerekli azotu sağlar, hem de bir miktar azotu kendinden sonra gelecek bitkiye sunar. $\mathrm{Bu}$ nedenle baklagiller iyi bir ekim nöbeti bitkisi olarak görülür. Fasulye bitkisinin diğer tarla bitkileriyle rotasyona tabi tutulması, ekilebilir alanlarda gübre ve enerji kullanımının azalmasında ve dolayısıyla sera gazı salınımının da azaltmasında önemli rolü üstlenmektedir (Stagnari ve ark. 2017). Bitki artıklarının yem olarak kullanılması da diğer bir artı katkısını oluşturmaktadır.

İklim koşullarının el verdiği her yörede çiftçiler tarafindan fasulye tarımı yapılmaktadır. Kuru taneleri normal oda sıcaklığında saklanabilmesi yani depolanması kolay olduğu için mutfakların vaz geçilmez ürünlerinden biridir. Bitkisel üretimde sıcaklık ve su faktörleri, bitkinin gelişmesine ve verimi üzerine en etkili olan faktörler olduğu bilinmektedir. (Masaya ve White, 1991, Önder ve Kahraman, 2010). Fasulye kazık köklü, ılıman iklimi seven, soğuğa karşı çok hassas bir yapıya sahiptir. Çimlenmek için fasulye bitkisi, toprak sicaklığının en az $8^{\circ} \mathrm{C}$, optimum çimlenme sıcaklığının $18{ }^{\circ} \mathrm{C}$, gelişim sıcaklığı $20-25{ }^{\circ} \mathrm{C}$ olmasına gereksinim duymaktadır. Gelişme döneminde $15^{\circ} \mathrm{C}$ ' in altındaki sıcaklıkta gelişmenin yavaşlamasından, $32^{\circ} \mathrm{C}$ nin üstünde ise döllenmenin engellenmesinden dolayı verim düşüşü gerçekleşmektedir (Porch and Jadn, 2001). Fasulye bitkisi, organik maddesi az, toprak drenajı zayıf ve fazla asit barındıran toprakları sevmez. Doğu Anadolu'daki karasal iklimin hüküm sürdüğü Elazığ yöresinde kuru fasulye ekim tarihi 15 Mayıs-15 Haziran tarihleri arasında yapılmaktadır. Fasulye bitkisi suyu çok seven bir bitki olup baklalarında \% 90'a yakın su bulundurmaktadır (Salcedo, 2008)

Fasulye bitkisinin Anadolu'nun her yerinde farklı varyetelere rastlanması, insan besini olarak gerekliliği ve toprak koruma özelliği yönünle önemlilik arz etmesi, bölgelere uyum sağlayan çeşitlerin araştırılmasının gerekliliğini ortaya koymaktadır. Elazığ ilinde fasulye ekim alanı 6045 dekar olup verim ise $100-212 \mathrm{~kg} \mathrm{da}^{-1}$ arasında değişmektedir (Anonim
2020). Bölgeye uyum sağlayan ve yüksek verimli çeşitlerin tespiti bölge koşullarında yapılacak çalışmalarla belirlenmektedir. $\mathrm{Bu}$ nedenle Doğu Anadolu bölgesinde yer alan Elazı̆̆ yöresinde 11 fasulye çeşidi tarla koşullarında denenmiştir.

\section{MATERYAL ve METOD}

Deneme 2017 yılında Doğu Anadolu Bölge sınırları içinde Elazığ ili Maden ilçesinde 11 farklı fasulye (Önceler 98, Göynük 98, Yunus 90, Topçu, Aras 98, Alberto, Bermaz, Noyanbey 98, Akman 98, Göksun, Karacaşehir 98) çeşidi kullanılarak yürütülmüştür. Deneme alanının toprak hazırlığı Mayıs ayının ikinci haftası yapılmıştır. Ekim elle 27 Mayıs 2017 tarihinde, $50 \mathrm{~cm}$ sıra arası mesafesi ile $10 \mathrm{~cm}$ sira üzeri mesafesinde, $5 \mathrm{~m}$ uzunluğunda 4 sira ve dört tekerrürlü olarak, tesadüf blokları deneme planına göre yapılmıştır. Ekimle beraber dekara $6 \mathrm{~kg}$ saf fosfor $\left(\mathrm{P}_{2} \mathrm{O}_{5}\right)$ ve $2.2 \mathrm{~kg}$ azot $(\mathrm{N})$ düşecek şekilde gübre uygulanmıştır. Bitki boyu $10 \mathrm{~cm}$ olduğu zaman üst gübre olarak dekara saf $4 \mathrm{~kg}$ azot $(\mathrm{N})$ düşecek şekilde azotlu gübre uygulanmıştır. Yabancı ot mücadelesi iki kez el çapası şeklinde uygulanmıştır. Bitkilerin su gereksinimi Haziran ayının sonundan itibaren salma sulama ile karşılanmıştır. Sulama aralığı bitkini durumu ve toprak durumu gözlenerek 5-8 gün aralıklarla uygulanmıştır. Hasat Eylül ayının son haftasında bitkiler kurumaya başlayınca elle sökülerek gerçekleşmiştir.

Denemede kullanan fasulye çeşitlerinin çiçeklenme süreleri, bakla bağlama süreleri, bitki boyları, bakla yükseklikleri, bakla sayıları, dolu bakla sayıları, tane verim değerleri incelenmiştir. Araştırılan özelliklerin gözlem ve ölçümlerinde Çınar (2015)'den yararlanılmıştır.

Deneme alanının bulunduğu Elazığ ili Maden ilçesi karasal iklim özelliği gösterip yazın sıcak ve kurak, kışın soğuk ve kar yağışlı bir iklime sahiptir. Denemenin yürütüldüğü sezonda Mayıs ayı hariç diğer

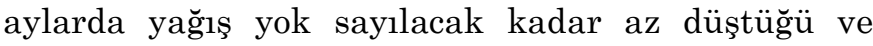
havanın nispi neminin de çok düşük olduğu Çizelge 1'de görülmektedir.

Çizelge 1. Deneme alanının 2017 yılına ait bazı meteorolojik verileri

Table 1. Some meteorological data of the trial area for 2017

\begin{tabular}{|l|c|c|c|c|c|}
\hline Aylar & \multicolumn{3}{|c|}{ Sicaklik (C) (Temperature) } & Ortalama nem (\%) & Yağış (mm) \\
& Min. & Max. & Ort (Mean). & (Mean humidity) & Precipitation) \\
Mayıs (May) & 7.7 & 29.5 & 17.3 & 53.6 & 59.0 \\
Haziran (June) & 13.9 & 39.0 & 24.5 & 30.9 & 0.2 \\
Temmuz (July) & 19.4 & 40.6 & 30.1 & 21.0 & 0.2 \\
Ağustos (August) & 18.2 & 42.0 & 29.7 & 21.0 & 2.2 \\
Eylül (September) & 13.5 & 38.6 & 26.3 & 21.0 & - \\
\hline
\end{tabular}

(Anonim, 2017)

Deneme alanının 0-20 cm derinlikten alınan toprak analizinde potasyum oranın $15.25 \mathrm{~kg} / \mathrm{da}(\mathrm{az})$, fosfor oranının $1.85 \mathrm{~kg} / \mathrm{da}$ (çok az), kireç oranın \%3.156(kireçli), organik madde miktarının \%2.54 (orta), toplam tuz oranın \%0.065 (tuzsuz), Ph oranının 8.15 (alkali), saturasyon'un 70.4 (killi) olduğu tespit edilmiştir (Anonim, 2018). 


\section{İstatistik Analizler}

Incelenen özelliklerden elde edilen veriler Anova yöntemine göre SAS istatistik programı kullanılarak analiz edilmiştir. Istatistiki olarak önemli farklılık gösteren özelliklerin ortalamaları Duncan çoklu karşılaştırma testine göre $(p<0.01)$ gruplandırılmıştır.

\section{BULGULAR ve TARTISSMA}

Araştırmada kullanan 11 farklı fasulye çeşidinin, çiçeklenme süresine, bakla bağlama süresine, bitki boyuna, bakla yüksekliğine, bakla sayısına, dolu bakla sayısına, tane verimine ait değerlerin ortalamaları ve oluşan gruplar Çizelge 2'de verilmiştir. Fasulye çeşitleri arasında çiçeklenme süreleri, bakla bağlama süreleri, bitki boyları, bakla yükseklikleri, bakla sayıları yönünden istatistiki olarak önemli $(p<0.01)$ farklılıkların olduğu kaydedilmiştir.

Elazığ bölgesinde 11 fasulye çeşidi ile yürütülen çalışmada en erken çiçeklenme süresi 53 günle Aras 98 ve Karacaşehir 98 çeşitlerinde gerçekleştiği ve diğer çeşitlerden istatistiki olarak önemli farklılık oluşturduğu görülmüştür. Fasulye çeşitlerinde en geç çiçeklenme 60 günle Akman 98 çeşidinde kaydedildiği diğer çeşitlerden istatistiki olarak farklılık oluşturduğu belirlenmiştir. Geç çiçeklenmeyi ikinci sırada 59 günle Topçu ve Alberto çeşidinin izlediği ve bunların diğer çeşitlerden istatistiki olarak önemli derece farklılığa sahip olduğu kaydedilmiştir. Önceler 98, Yunus 90 ve Noyanbey 98 çeşitlerinin 58 günde çiçeklenme göstererek üçüncü sırada yer aldığı ve diğerlerinden istatistiki olarak farklılık gösterdiği tespit edilmiştir. Göynük 98, Göksu, Bermaz çeşitlerini çiçeklenme süreleri sırasıyla $57,56,55$ günde gerçekleştirdiği, kendi aralarında istatistiki farklılık oluşturmadığı, diğer çeşitlerden ise istatistiki olarak önemli farklılık oluşturduğu gözlemlenmiştir.

Çizelge 2. Fasulye çeşitlerinin çiçeklenme süresi, bakla bağlama süresi, bitki boyu, bakla yüksekliği, bakla sayısı ortalamaları ve grupları.

Table 2. The average and groups of flowering period, seed set period, plant height, pod height, pod number of bean varieties.

\begin{tabular}{|c|c|c|c|c|c|}
\hline $\begin{array}{l}\text { Genotipler } \\
\text { (Genotypes) }\end{array}$ & $\begin{array}{l}\text { Çiçeklenme } \\
\text { süreleri(gün)** } \\
\text { (Flowering } \\
\text { period) }\end{array}$ & $\begin{array}{l}\text { Bakla bağlama } \\
\text { süreleri(gün)** } \\
\text { (Seed set } \\
\text { period) }\end{array}$ & $\begin{array}{l}\text { Bitki } \\
\text { boyları }(\mathrm{cm}) \\
(\text { Plant height })\end{array} * *$ & $\begin{array}{l}\text { Bakla } \\
\text { yükseklikleri }(\mathrm{cm})^{* *} \\
(\text { Pod height) }\end{array}$ & $\begin{array}{ll}\text { Bitkide } & \text { bakla } \\
\text { sayıları } \\
\text { (adet) ** } \\
\text { number) }\end{array}$ \\
\hline Önceler 98 & $58.00 \pm 2.3 \mathrm{c}$ & $78.00 \pm 2.3 \mathrm{f}$ & $54.00 \pm 0.55 \mathrm{c}$ & $19.45 \pm 0.44 \mathrm{~d}$ & $22.55 \pm 3.88 \mathrm{~cd}$ \\
\hline Göynük 98 & $57.00 \pm 2.3 \mathrm{~d}$ & $80.00 \pm 2.3 \mathrm{e}$ & $55.80 \pm 0.28 \mathrm{c}$ & $21.30 \pm 0.62 \mathrm{c}$ & $34.55 \pm 8.98 \mathrm{ba}$ \\
\hline Yunus 90 & $58.00 \pm 2.3 \mathrm{c}$ & $77.00 \pm 2.3 \mathrm{f}$ & $60.57 \pm 0.45 \mathrm{~b}$ & $27.05 \pm 0.34 \mathrm{a}$ & $30.50 \pm 12.50 \mathrm{bc}$ \\
\hline Topçu & $59.00 \pm 2.3 \mathrm{~b}$ & $85.00 \pm 2.3 \mathrm{bc}$ & $52.85 \pm 0.47 \mathrm{~d}$ & $14.65 \pm 0.44 \mathrm{f}$ & $22.85 \pm 6.91 \mathrm{~cd}$ \\
\hline Aras 98 & $53.00 \pm 2.3 \mathrm{~g}$ & $82.00 \pm 2.3 \mathrm{~d}$ & $62.45 \pm 2.27 \mathrm{a}$ & $22.40 \pm 0.36 \mathrm{~b}$ & $25.40 \pm 6.69 \mathrm{bcd}$ \\
\hline Alberto & $59.00 \pm 2.3 \mathrm{~b}$ & $91.00 \pm 2.3 \mathrm{a}$ & $49.90 \pm 0.47 \mathrm{e}$ & $12.92 \pm 0.49 \mathrm{~h}$ & $17.15 \pm 6.32 \mathrm{~d}$ \\
\hline Bermaz & $55.00 \pm 2.3 \mathrm{f}$ & $86.00 \pm 2.3 \mathrm{~b}$ & $48.85 \pm 0.33 \mathrm{e}$ & $20.90 \pm 0.57 \mathrm{c}$ & $23.55 \pm 4.25 \mathrm{~cd}$ \\
\hline Noyanbey 98 & $58.00 \pm 2.3 \mathrm{c}$ & $80.00 \pm 2.3 \mathrm{e}$ & $48.85 \pm 0.25 \mathrm{e}$ & $18.10 \pm 0.41 \mathrm{e}$ & $33.70 \pm 7.25 \mathrm{~b}$ \\
\hline Akman 98 & $60.00 \pm 2.3 \mathrm{a}$ & $84.00 \pm 2.3 \mathrm{c}$ & $35.32 \pm 12.49 \mathrm{f}$ & $13.80 \pm 0.28 \mathrm{~g}$ & $34.75 \pm 9.75 \mathrm{ab}$ \\
\hline Göksun & $56.00 \pm 2.3 \mathrm{e}$ & $81.00 \pm 2.3 \mathrm{de}$ & $33.22 \pm 0.50 \mathrm{~g}$ & $13.65 \pm 0.34 \mathrm{~g}$ & $28.95 \pm 6.03 \mathrm{bc}$ \\
\hline $\begin{array}{l}\text { Karacaşehir } 98 \\
\text { C.V. }\end{array}$ & $\begin{array}{l}53.00 \pm 2.3 \mathrm{~g} \\
4043\end{array}$ & $\begin{array}{l}78.00 \pm 2.3 \mathrm{f} \\
4.93\end{array}$ & $\begin{array}{c}34.90 \pm 062 \mathrm{~g} \\
1839\end{array}$ & $\begin{array}{r}13.70 \pm 0.11 \mathrm{~g} \\
1823\end{array}$ & $43.60 \pm 11.68 \mathrm{a}$ \\
\hline
\end{tabular}

**: p < 0.01, Aynı harflerle gösterilen ortalamalar arasındaki farklılıklar istatistiki olarak önemsizdir.

Fasulye genotipleri çiçeklenme süresi yönünden birbirlerinden farklı 7 grup oluşturduğu kaydedilmiştir (Çizelge 2). Altı fasulye genotipi ile iki yıllık çalışmada Pekşen (2005) çiçeklenme periyodu 23.50-64.80 gün arasında değiştiğini belirlemiştir. Fasulyenin çiçeklenme sürelerinin, Atıcı (2013) Giresun koşullarında 30-88 gün, Servia ve ark (2016) Meksika'da farklı eyaletlerde yerel çeşitlerin bölgelere göre 44-92 gün arasında değiştiğini tespit etmişlerdir. Mideksa Egu ve Tesfaye (2018), Melkassa'da 25 fasulye genotipiyle yapmış oldukları çalışmada çiçeklenme gün sayısının stres koşullarında \% 12.6 azaldığını vurgulamışlardır. Çiçeklenme süresinin Yeken ve ark.(2019) 80 fasulye genotipinde 45-69 gün, Nadeem ve arkadaşları (2020) 183 fasulye genotipinde lokasyonlara göre 61-68 gün arasında değiştiğini kaydetmişlerdir. Daha önceki araştırmalardan da anlaşıldığı gibi fasulyenin çiçeklenme süresi çeşide, iklim koşullarına, çevre özelliğine, uygulanan faktörlere göre değişim gösterdiği belirlenmiştir. Yapılan araştırmada kullanılan çeşitlerin çiçeklenme gün sayısı yönünden birbirinden farklı 7 grup oluşturması, çeşitler arasındaki farklılığın önemini ortaya koymaktadır.

Denemede kullanılan fasulye çeşitlerinin \% 50 bakla oluşuncaya kadar geçen sürenin 77 gün ile 91 gün arasında değiştiği tespit edilmiştir. Alberto çeşidinin 91 günle en geç bakla bağladığ ve istatistiki olarak diğer çeşitlerden önemli farklılık oluşturduğu kaydedilmiştir. Bakla bağlamayı 86 günde gerçekleştiren Bermaz çeşidi, 84 günle Akman 98 çeşidi kendi aralarında ve diğer çeşitlerden istatistiki olarak önemli farklılık oluştururken, Topçu çeşidi Bermaz ve Akman 98 çeşidi arasında geçiş grubunu 
oluşturduğu kaydedilmiştir. Göynük 98 ve Noyanbey 98 çeşitlerinin 80 günde bakla bağladığı kendi aralarında istatistiki farklılık oluşturmadığı diğer çeşitlerden ise istatistiki olarak önemli farklılık oluşturduğu, Göksün çeşidinin 81 günde, Göynük 98 ve Noyanbey 98 ile Aras 98 çeşidi arasında geçiş grubunu oluşturmuştur. Aras çeşidi 82 günde bakla bağlayarak istatistiki olarak diğer çeşitlerden önemli farklılık oluşturduğu kaydedilmiştir. En erken 77 günle bakla bağlayan Yunus 90 çeşidi, 78 günde bakla bağlayan Önceler 98 ve Karacaşehir 98 çeşitleri kendi aralarında istatistiki farklılık oluşturmadığı diğer çeşitlerden ise istatistiki olarak önemli farklılık oluşturduğu belirlenmiştir (Çizelge 2). Fasulyede bakla bağlama süresini, Anlarsal ve ark.(2000) Çukurova ekolojik şartlarında yaptıkları iki yıl süren çalışmada Şeker-Malatya çeşidinin 46 gün, Boylu (2019) Kahramanmaraş koşullarında 16 yerel fasulye çeşidiyle iki yıl yürütülen araştırmada 62.2-78.3 gün arasında, Yeken ve ark. (2019) 80 fasulye genotipinde 53-73 gün arasında değiştiğini kaydetmişlerdir. Daha önceki araştırıcıların yapmış olduğu çalışmalardan da anlaşıldığı gibi bakla bağlama süresinde çeşit faktörü etkili olurken, Çukurova koşullarında daha erken olması sicaklık faktörünün etkisi olduğu anlaşılmaktadır. Bakla bağlama süresinin daha önceki araştırıcıların sonuçlarına göre daha uzun olması, araştırmanın yapıldığı yerde daha serin iklim yapısına sahip olmasından kaynaklanmıştır.

Fasulye çeşitlerin bitki boyları $62.45 \mathrm{~cm}$ ile $33.22 \mathrm{~cm}$ arasında değiştiği kaydedilmiştir. Aras 98 çeşidinin $62.45 \mathrm{~cm}$ (a grubu) ile en yüksek bitki boyuna sahip olduğu ve istatistiki olarak diğer çeşitlerden önemli farklılık oluşturduğu tespit edilmiştir. Yunus 90 çeşidinin $60.57 \mathrm{~cm}(\mathrm{~b}$ grubu) ile ikinci surada olup istatistiki olarak diğer çeşitlerden önemli farklılık oluşturduğu tespit edilmiştir. Göynük 98 çeşidinin ve Önceler 98 çeşidinin aynı (c) grubta yer alarak diğer çeşitlerden ise istatistiki olarak önemli farklılık oluşturduğu gözlemlenmiştir. Topçu çeşidinin 52.85 $\mathrm{cm}$ bitki boyu(d grubu) ile istatistiki olarak diğer çeşitlerden önemli farklılık oluşturduğu tespit edilmiştir. Alberto, Bermaz, Noyanbey aynı grupta (e) yer alarak diğer çeşitlerden istatistiki olarak önemli farklılık oluşturduğu gözlemlenmiştir. Akman 98 çeşidinin $35.32 \mathrm{~cm}$ (f grubu) ile diğer çeşitlerden önemli farklılık oluşturduğu tespit edilmiştir. Karacaşehir 98 ve Göksün çeşidinin kendi aralarında istatistiki farklılık oluşturmadığı diğer çeşitlerden ise istatistiki olarak önemli farklılı oluşturduğu gözlemlenmiştir (Çizelge 2). Bitki boylarının, Düzdemir (1998), Tokat ilinde koşullarında fasulye genotiplerinde 44.85-133.78 cm arasinda, Kahraman ve Önder (2009) Konya koşularında 42 fasulye çeşidinde $31.23-112.23 \mathrm{~cm}$ arasında değiştiğini kaydetmişlerdir. Çavuşoğlu ve Akçin (2007) iki bodur fasulye çeşidiyle yapmış oldukları çalışmada; Roma-II çeşidi $41.15 \mathrm{~cm}$ ile Nassau çeşidine göre $(35.18 \mathrm{~cm}) \% 5$ önem seviyesinde farklılık gösterdiğini kaydetmişlerdir. Fasulye bitkisinin bitki boylarının, Güçlü ve Önder (2019) Konya koşullarında üç standart ve 100 genotipde 5.28-218.61 cm arasinda, Yeken ve ark. (2019) 80 fasulye genotipinde 25.25-261.50 cm arasında, Nadeem ve arkadaşları (2020) 183 fasulye genotiplere göre $21.0-168.7 \mathrm{~cm}$ ve lokasyonlara göre 25.2-52.1 cm arasında değiştiğini tespit etmişlerdir. Daha önceki araştırıcıların yapmış oldukları çalışmalardanda anlaşılacağı gibi, fasulyede bitki boyu çeşitlere ve lokasyonlara göre değişkenlik göstermektedir, bu nedenle çeşitler arasındaki farklılı bölgesel olarak denenerek ortaya çıkarılabilinecektir.

Araştırmada kullanılan 11 farklı çeşitlerin bakla yüksekliklerinin $12.92 \mathrm{~cm}$ ile $27.05 \mathrm{~cm}$ arasında değiştiği gözlemlenmiştir. Yunus 90 çeşidinin 27.05 cm(a grubu) ile en yüksek bakla yüksekliğine sahip olarak diğer çeşitlerden önemli farklılık gösterdiği, onu $22.40 \mathrm{~cm}$ ile Aras 98 çeşidinin izlediği tespit edilmiştir. Göynük 98 çeşidinin $21.30 \mathrm{~cm}$ ve Bermaz çeşidinin ise $20.90 \mathrm{~cm}$ bakla yüksekliği aynı grupta (c) yer aldığı diğer çeşitlerden istatistiki olarak önemli farklılık oluşturduğu tespit edilmiştir. Akman 98, Karacaşehir, Göksün kendi aralarında istatistiki farklılık oluşturmadığı diğer çeşitlerden istatistiki olarak önemli farklılık oluşturduğu gözlemlenmiştir. Alberto çeşidinin ise $12.92 \mathrm{~cm}$ (h grubu) ile en az bakla yüksekliğine sahip olduğu ve diğer çeşitlerden istatistiki olarak önemli farklılık oluşturduğu tespit edilmiştir. Bakla yüksekliği yönünden çeşitler birbirinden farklı 7 grup oluşturmuştur (Çizelge 2). Bakla yüksekliklerini, Babagil ve ark. (2011) Erzurum iklim koşullarında $13.3 \mathrm{~cm}$, Girgel ve ark (2018) Bayburt koşullarında 3 çeşit ve 13 yerel genotipte 6.7$11.1 \mathrm{~cm}$ arasında, Güçlü ve Önder (2019) Konya koşullarında fasulyenin üç standart çeşit ve 100 genotip üzerinde 6.78-24.45 $\mathrm{cm}$ arasında, Nadeem ve arkadaşları (2020) 183 fasulye genotipinin lokasyonlara göre 8.0-15.5 cm arasında değiştiğini belirtmişlerdir. Bakla yüksekliği çeşit özelliklerine bağlı olmakla birlikte, toprak yapısı, gelişme döneminde havalarin sicak gitmesi ve sulama faktörlerden etkilemektedir. Bakla yüksekliği tarımsal uygulamalar yönünden önemli bir özelliktir. Araştırmada kullanılan çeşitler arasında varyasyonun elde edilmesi, çeşit seçimini kolaylaştırmaktadır. Çeşit seçimi tek bir özellikle değil, vejatasyon süresi, verim gibi özelliklerde dikate alınarak yapılmalıdır. Daha önceki araştıcıların yapmış oldukları çalışmalarda da varyanyon elde edildiği görülmektedir.

Fasulye çeşitlerinin bitkideki bakla sayıları 17.1543.60 adet arasında değiştiği kaydedilmiştir. Karacaşehir 98 çeşidi 43.60 bakla sayısı(a grubu) ile en yüksek bitkide bakla sayısına sahip olduğu, onu ikinci sırada Akman 98, üçüncü sırada Göynük 98 çeşidinin 
izlediği, kendi aralarında istatistiki farklılık oluşturmadığı diğer çeşitlerden istatistiki olarak önemli farklılık oluşturduğu tespit edilmiştir. En düşük baklada sayısını 17.15 adet (d grubu) ile Alberto çeşidinde görüldüğü, onu sırasıyla Önceler 98, Topçu, Bermaz, Aras 98 çeşitlerinin izlediği, Alberto çeşidi ile aralarında istatistiki olarak farklılık oluşturmadığı geçiş grubunu oluşturduğu kaydedilmiştir. Alberto çeşidi Göynük 98, Yunus 90, Noyanbey 98, Akman 98, Göksun, Karacaşehir 98 çeşidinden istatistiki olarak önemli farklılık oluşturduğu belirlenmiştir (Çizelge 2). Bitkideki bakla sayısıyla ilgili yapılan çalışmada Feher ve Pitış (1971) 5.6 adet, olduğunu gözlemlemişlerdir. Chung ve Goulden (1971) yaptıkları çalışmada yeni Zelenda iklim koşullarında tane verimi ile bitkide bakla sayısı arasında önemli ve pozitif bir bağlantı olduğunu tespit etmişlerdir. Mourice ve Tryphone (2012) farkl fosfor doz uygulamasını denedikleri yedi fasulye genotipide bitkideki bakla sayısının çeşitlere göre değiştiğini vurgulamışlardır. Duarte ve Adams (1972) ABD'de yaptıkları çalışmada fasulyede alınan verimde bakla sayısının önemli bir etken olduğunu belirtmişlerdir. Bakla sayısını, Vakali ve ark(2009) Yunanistan'da yerel fasulye çeşitlerinde 49-101 adet arasında, Mideksa (2016), Melkassa-Ethiopia'da, 12 fasulye genotipinde 25.3-37.6 adet ve kuraklı stresi uyguladığında 18.1-30.9 adet arasında, Girgel ve ark. (2018) Bayburt koşullarında 3 çeşit ve 13 yerel genotipte 10.0-24.1 adet arasında değiştiğini a kaydetmiştir. Mideksa Egu ve Tesfaye (2018) Melkassa 25 fasulye genotipiyle yapmış oldukları çalışmada bitkideki bakla sayısının genotiplere göre su stresi karşısında \% $11.5^{-} \quad 40.7$ azaldığını vurgulamışlardır. Bakla sayısını, Yeken ve ark. (2019) 80 fasulye genotipinde 6.67-63 adet arasında, Nadeem ve arkadaşları (2020) 183 fasulye genotipinde lokasyonlara göre 9.8-18.5 adet arasında değiştiğini belirtmişlerdir. Fasulyede bakla sayılarının, iklim, çevre, uygulama faktörleri ve çeşit özeliklerine göre farklılık gösterdiği daha önceki araştırıcılar tarafından vurgulanmıştır. Bakla sayısı tane verimini belirleyen faktörlerden biridir. Bu nedenle, çeşitler arasında bakla sayısı yönünden farklılıkların elde edilmesi önemlilik arz etmektedir.

Elazığ bölgesinde 11 fasulye çeşidi ile yapılan çalışmada dolu bakla sayılarına 43.40-16.57 adet arasında değiştiği gözlemlenmiştir. En yüksek 43.40 adet dolu bakla sayısı(a grubu) ile Karacaşehir çeşidinin diğer çeşitlerden istatistiki olarak önemli farklılık oluşturduğu tespit edilmiştir. Akman 98, Göynük 98, Noyanbey 98 çeşitleri aynı (b) grupta yer alarak, Yunus 90, Göksun ve Aras 98 çeşidi hariç, diğer çeşitlerden istatistiki olarak önemli farklılık oluşturduğu tespit edilmiştir. Öncüler 98, Topçu ve Bermaz çeşitleri 22.40, 22.35 ve 23.40 adet dolu baklaya sahip olduğu ve istatistiki olarak birbirlerinden farklılık oluşturmayıp aynı grupta yer aldığı kaydedilmiştir. En az dolu bakla sayısı 16.57 adet ile Alberto çeşidinin sağladığı ve diğer çeşitlerden istatistiki olarak önemli farklılık oluşturduğu tespit edilmiştir (Çizelge 3). Mideksa Egu ve Tesfaye (2018), Melkassa'da 25 fasulye genotipiyle yapmış oldukları çalışmada bitkideki bakla sayısının genotiplere göre su stresi karşısında \%11.5-40.7 azaldığını vurgulamışlardır. Boylu (2019) Kahramanmaraş koşullarında 16 yerel fasulye çeşidiyle iki yıl yürütülen araştırmada dolu bakla sayısının 2.55-16.75 adet arasında değiştiğini kaydetmiştir. İklim ve çevresel koşulları dolu bakla sayısını etkilenmektedir. Bakla doldurma döneminde bitkinin sicaklara tepkisi önemlidir. Sicaklara toleransa, bitkinin kökünün derinlere yayılması yanı sıra, yaprak yapısı da etkili olmaktadır. Topraktaki besin maddesi, toprak yapısı ve nem durumu da bakladaki doluluk oranına etkide bulunmaktadır.

Elazığ iklim koşullarında yapılan çalışmada fasulye çeşitlerinin hasat sürelerinin Önceler 98, Göynük 98, Yunus 90, Aras 98, Bermaz, Noyanbey 98, Karacaşehir 98 çeşitlerinde 115 gün, Göksün ve Topçu çeşitlerinde 115.75 gün, Akman 98 ve Alberto çeşitlerinde ise 116.25 gün olduğu tespit edilmiştir. Çizelge 3'den de görüldüğü gibi fasulye çeşitleri hasat süreleri yönünden önemli farklılık göstermediği tespit edilmiştir. Olgunluk sürelerini, Güçlü ve Önder (2019) Konya koşullarında üç standart fasulye çeşidi ile 100 genotipte 95.94-138.27 gün, Yeken ve ark. (2019) 80 fasulye genotipinde 90-141 gün arasında değiştiğini kaydetmişlerdir. Nadeem ve arkadaşları (2020) 183 fasulye genotipte olgunluk gün sayısının çeşitlere göre 99-161 gün, lokasyonlara göre 107-129 gün arasında değiştiğini, olgunlaşma gün sayısının seçim kriteri olarak önemlilik arz ettiğini belirtmişlerdir.

Elazığ iklim koşullarında denenen fasulye çeşitlerinde en az tane verimin Alberto çeşidinde $141.43 \mathrm{~kg} \mathrm{da}{ }^{-1}$ olarak elde edildiği, Alberto çeşidini ikinci sırada Topçu çeşidi $171.80 \mathrm{~kg} \mathrm{da}^{-1}$, Akman 98 çeşidi $193.13 \mathrm{~kg}$ $\mathrm{da}^{-1}$, Göksün çeşidinin $235.70 \mathrm{~kg} \mathrm{da}^{-1}$ ile izlediği ve kendi aralarında istatistiki farklılık oluşturmadığı, diğer çeşitlerden istatistiki olarak önemli farklılık oluşturduğu kaydedilmiştir. Fasulye çeşitleri arasında en yüksek tane verimi $333.10 \mathrm{~kg}^{-1} \mathrm{da}^{-1}$ ile Aras 98 çeşidinden sağlandığı, onu sirasıyla Yunus 90 çeşidinin $326.68 \mathrm{~kg} \mathrm{da}^{-1}$, Göynük 98 çeşidinin 325.28 $\mathrm{kg} \mathrm{da}^{-1}$, Önceler 98 çeşidinin $318.13 \mathrm{~kg} \mathrm{da}^{-1}$, Bermaz çeşidinin $287.58 \mathrm{~kg}$ da ${ }^{-1}$ Noyanbey 98 çeşidinin 282.60 $\mathrm{kg} \mathrm{da}{ }^{-1}$, Karacaşehir 98 çeşidinin $268.65 \mathrm{~kg} \mathrm{da}^{-1}$ ile izlediği tespit edilmiştir. Aras 98, Yunus 90, Göynük 98, Önceler 98 çeşitleri istatistiki olarak Alberto, Topçu ve Akman 98 çeşitlerinden tane verimi yönünden önemli derecede farklılık oluşturduğu belirlenmiştir. Fasulye bitkisinin tane verimiyle ilgili yapılan çalışmalarda, Çiftçi ve Yılmaz (1992), Van ilinde 124-198 kg da ${ }^{-1}$ arasında değiştiğini, Bozoğlu ve 
Gülümser (2000) Samsun koşullarında 162.7-237.7 kg da ${ }^{-1}$ arasında, Hakyemez ve ark, (2005) Çanakkale ilinde en yüksek tane verimini Göynük-98 çeşidinden $116.4 \mathrm{~kg} \mathrm{da}^{-1}$, Firtına (2006) Van ilinin Gevaş ilçesinde en yüksek verimin $472.0 \mathrm{~kg} \mathrm{da}^{-1}$ ile $\mathrm{Aras}^{-} 98$ çeşidinde, en az verimi ise $285.0 \mathrm{~kg} \mathrm{da}^{-1}$ Şeker çeşidinde, Ceyhan ve ark. (2009) $322.2^{-} 850 \mathrm{~kg} \mathrm{da}^{-1}$ arasında değiştiğini tespit etmişlerdir. Mourice ve Tryphone (2012) farklı fosfor doz uygulamasinı denedikleri yedi fasulye genotipinde tane veriminin $299-514 \mathrm{~kg} \mathrm{da}^{-1}$ arasinda değiştiğini belirmişlerdir. Mideksa (2016), MelkassaEthiopia'da 25 fasulye genotipinin tane verimleri $147.5-194.7 \mathrm{~kg} \mathrm{da}^{-1}$ ve kuraklık stresi uyguladığında
72.5-125.3 $\mathrm{kg} \mathrm{da}{ }^{-1}$ arasında olduğunu kaydetmiştir. Mideksa Egu ve Tesfaye (2018), Melkassa'da 25 fasulye genotipyle yapmış oldukları çalışmada tane veriminin $147.7-195.8 \mathrm{~kg} \mathrm{da}^{-1}$ arasında değiştiğini tespit etmişlerdir. Daha önceki araştırıcıların elde ettikleri sonuçlardan da anlaşılacağı gibi, tane verimi çeşide, çevresel faktörlere ve kültürel uygulamakara göre varyasyon göstermektedir. Ekoloji uyum araştırmasında, çeşitler arasındaki varyasyonlar dikate alınırken, verime bağlı özeliklerin birlikte incelenmesi ve vejatasyon süresinin dikkate alınması yapıcak çeşit seçiminde başarıyı artıracaktır.

Çizelge 3. Fasulye çeşitlerinin dolu bakla sayıları, olgunluk süreleri, tane verimlerinin ortalamaları ve grupları

Table 3. The average and groups of filled pod number, ripening period and grain yield of bean varieties.

\begin{tabular}{|l|l|c|c|}
\hline Genotipler (Genotypes) & $\begin{array}{l}\text { Dolu bakla saylarl(adet) } \\
\text { (Filled pod number) }\end{array}$ & $\begin{array}{c}\text { Olgunluk süreleri(gün) } \\
\text { (Ripening period) }\end{array}$ & $\begin{array}{l}\text { Tane verimleri(kg da }{ }^{-1} \text { ) ** } \\
\text { (Grain yield) }\end{array}$ \\
Onceler 98 & $22.40 \pm 3.88 \mathrm{~cd}$ & $115.00 \pm 0.81$ & $318.13 \pm 93.00 \mathrm{a}$ \\
Göynük 98 & $33.90 \pm 9.85 \mathrm{~b}$ & $115.00 \pm 0.81$ & $325.28 \pm 156.15 \mathrm{a}$ \\
Yunus 90 & $29.70 \pm 12.50 \mathrm{bc}$ & $115.00 \pm 0.81$ & $326.68 \pm 204.24 \mathrm{a}$ \\
Topçu & $22.35 \pm 7.38 \mathrm{~cd}$ & $115.75 \pm 0.95$ & $171.80 \pm 128.58 \mathrm{bc}$ \\
Aras 98 & $25.40 \pm 6.69 \mathrm{bcd}$ & $115.00 \pm 0.81$ & $333.10 \pm 152.58 \mathrm{a}$ \\
Alberto & $16.57 \pm 6.50 \mathrm{~d}$ & $116.25 \pm 0.95$ & $141.43 \pm 80.24 \mathrm{c}$ \\
Bermaz & $23.40 \pm 3.97 \mathrm{~cd}$ & $115.00 \pm 0.81$ & $287.58 \pm 172.72 \mathrm{ab}$ \\
Noyanbey 98 & $33.25 \pm 7.02 \mathrm{~b}$ & $115.00 \pm 0.81$ & $282.60 \pm 158.81 \mathrm{ab}$ \\
Akman 98 & $34.20 \pm 9.50 \mathrm{~b}$ & $116.25 \pm 0.95$ & $193.13 \pm 88.97 \mathrm{bc}$ \\
Göksun & $28.27 \pm 5.97 \mathrm{bc}$ & $115.75 \pm 0.95$ & $235.70 \pm 82.45 \mathrm{abc}$ \\
Karacaşehir 98 & $43.40 \pm 11.94 \mathrm{a}$ & $115.00 \pm 0.81$ & $268.65 \pm 94.24 \mathrm{ab}$ \\
C.V. & 21.00 & 0.667 & 28.494 \\
\hline
\end{tabular}

**: p < 0.01, Aynı harflerle gösterilen ortalamalar arasındaki farklılıklar istatistiki olarak önemsizdir.

\section{SONUÇ}

Doğu Anadolu bölgesinin Elazığ yöresinde 11 farklı fasulye çeşidi kullanılarak yürütülen çalışmada, Önceler 98, Göynük 98, Yunus 90, Aras 98 çeşitlerinin diğer çeşitlerden daha yüksek kuru fasulye tane verimine sahip olması ve aynı zamanda olgunlaşma süresini tamamlamaları nedeniyle önerilecek çeşitler olarak kabul edilmiştir. Araştırmanın sonraki yıllarda da sürdürülmesinde yarar vardır.

\section{TEŞEKKÜR}

Araştırma Tolga KARABACAK'ın Yüksek Lisans tezinden üretilmiştir.

\section{Araştırmacıların Katkı Oranı Beyan Özeti}

Yazarlar makaleye eşit oranda katkı sağlamış olduklarını beyan eder.

\section{Çıkar Çatışması Beyanı}

Makale yazarları aralarında herhangi bir çıkar çatışması olmadığını beyan ederler.

\section{KAYNAKLAR}

Anlarsal AE, Yücel C, Özveren D 2000. Çukurova Koşullarında Bazı Fasulye (Phaseolus vulgaris L.) Çeşitlerinde Tane Verimi ve Verimle İlgili
Özellikler ile bu Özellikler Arası İlişkilerin Saptanması. Turkish Journal of Agriculture and Forestry, 24: 19-29.

Anonim 2017. T.C Orman ve Su İşleri Bakanlığı Elazığ Meteoroloji Bölge Müdürlüğü.

Anonim 2018. Elazığ Gıda Tarım ve Hayvancılık İl Müdürlüğü Toprak Analiz Laboratuvarı.

Anonim 2020. Elazığ İl Tarım ve Orman Müdürlüğü, Tarla Bitkileri İstatistikleri. Elazığ.

Atıcı ÖF 2013. Giresun İlinde Toplanan Yerel Fasulye( Phaseolusvulgaris L.) Genotiplerinin Bazı Bitkisel Özellikleri ile Verim ve Verim Öğelerinin Belirlenmesi. Ordu Üniversitesi Fen Bilimleri Enstitüsü Tarla Bitkileri Anabilim Dalı, Yüksek Lisans Tezi, 63 sy.

Boylu ÖA 2019. Doğu Akdeniz Bölgesinde Yetişen Yerel Fasulye (Phaseolus Vulgaris L.) Genotiplerinin Morfolojik, Agronomik, Kalite Ve Moleküler Özellikler Yönünden Karakterizasyonu. Kahramanmaraş Sütçü İmam Üniversitesi Fen Bilimleri Enstitüsü Tarla Bitkileri Anabilim Dalı, Doktora Tezi, 117 sy.

Babagil GE, Tozlu E, Dizikısa T 2011. Erzincan ve Hınıs ekolojik koşullarında yetiştirilen bazı kuru fasulye(Phaseolus vulgaris L.) genotiplerinin verim ve verim unsurlarının belirlenmesi, Atatürk Üniv. Ziraat Fak. Derg., 42 (1): 11-17. 
Bozoğlu H, Gülümser A 2000. Kuru Fasulyede (Phaseolus vulgaris L.) Bazı Tarımsal Özelliklerin Genotip Çevre Interaksiyonları ve Stabilitelerinin Belirlenmesi Üzerine Bir Araştırma. Turkish Journal of Agriculture and Forestry, 24: 211-220.

Chung JH and Goulden DS 1971. Yield Components of Haricot Beans (Phaseolus vulgaris L) Grown at Different Plant Densities. New Zealand Journal of Agricultural Research, 14:227-234.

Çavuşoğlu A, Akçin A 2007. Taze Fasulye (Phaseolus vulgaris L.) Çeşitlerinde Farklı Gübre Kombinasyonlarının Verim ve Verim Unsurları Üzerine Etkileri. Selçuk Üniversitesi Ziraat Fakültesi Dergisi, 21 (43): 106-111.

Çınar T 2015. Bazı Kuru Fasulye (Phaseolus vulgaris L.) Genotiplerinin Erzurum Ekolojik Koşullarına Adaptasyonu ve Tarımsal Özellikleri. Atatürk Üniversitesi Fen Bilimleri Enstitüsü Tarla Bitkileri Anabilim Dalı, Yüksek Lisans Tezi, 77 sy.

Duarte RA, Adams MW 1972. A Pathcoefficientanalysis of Some Yield Component Interrelation in Field Bean (Phaseolus vulgaris L.). Crop Science, 12:579- 582.

Düzdemir O 1998. Kuru Fasulye (Phaseolus vulgaris L.) Genotiplerinde Verim ve Diğer Bazı Özellikler Üzerine Bir Araştırma. Gazi Osman Paşa Üniversitesi, FBE Yüksek Lisans Tezi.

Feher E, Pıtış SA 1971. Comparative Study of Some Varieties and Populations of Beans Grown for Seed in the Pedoclimatic Conditions of the Experimantal Didactic Station Ranu-Maracine. Biologiee.Stiinte Agricoie, 3: 225-231.

Girgel Ü, Çokkızgın A, Çölkesen M 2018. Bayburt Koşullarında Organik Olarak Yetiştirilen Bazı Yerel Fasulye (Phaseolus vulgaris L.) Genotiplerinin Bazı Morfolojik ve Agronomik Özelliklerinin Belirlenmesi Üzerine Bir Araştırma. Türk Tarım - Gıda Bilim ve Teknoloji Dergisi, 6(5): 530-535.

Güçlü M, Önder M 2019. Agronomic Characteristics of Domestic and Abroad Originated Bean (Phaseolus vulgaris L.) Genotypes. Selcuk J Agr Food Sci, 33 :2, 148-153.

Kahraman A, Önder M 2009. Konya Bölgesinde Yetiştirilen Kuru Fasulye (Phaseolus vulgaris L.) Genotiplerinde Verim ve Bazı Verim Öğelerinin Belirlenmesi. Türkiye VIII. Tarla Bitkileri Kongresi, 19 - 22 Ekim 2009, Hatay,Cilt1 : 309-313.

Mideksa A 2016. Evaluation of Morphological Aspects of Common Bean (Phaseolus vulgaris L.) Genotypes for Post-Flowering Drought Resistance in Rift Valley of Ethiopia. African Journal of Agricultural Research. 11(32): 3020-3026.

Mideksa Egu A, Tesfaye K 2018. Morpho-Physiological Characterization Related to Drought Tolerance of Common Bean (Phaseolus Vulgaris L.) Genotypes. International Journal of Advanced Biological and Biomedical Research 6(1): 39-46.
Mourice SK, Tryphone GM 2012. Evaluation of Common Bean(Phaseolus vulgaris L.) Genotypes for Adaptation to Low Phosphorus. International Scholarly Research Network ISRN Agronomy. Volume 2012, Article ID 309614, 9 pages doi:10.5402/2012/309614.

Nadeem MA, Karaköy T, Yeken M Z, Habyarimana E, Hatipoglu R, Çiftçi V, Nawaz M A, Sönmez F, Shahid MO, Yang SH, Chung G, Baloch F S 2020. Phenotypic Characterization of 183 Turkish Common Bean Accessions for Agronomic, Trading, and Consumer-Preferred Plant Characteristics for Breeding Purposes. Agronomy 2020, 10, 272; doi:10.3390/agronomy10020272.

Pekşen E 2005. Samsun koşullarında bazı fasulye (Phaseolus vulgaris L.) genotiplerinin tane verimi ve verimle ilgili özellikler bakımından karşılaştırılması. OMÜ Ziraat Fakültesi Dergisi, 20 (3): 88-95.

Porch TG, Jahn, MM 2001. Effects of HighTemperature Stress on Microsporogenesis in HeatSensitive and Heat-Tolerant Genotypes of Phaseolus Vulgaris. Plant, Cell and Environment, 24:723-731. DOI:10.1046/j.13653040.2001.00716.xCorpus ID: 85601079

Rochfort S, Panozzo J 2007. Phytochemicals for Health, the Role of Pulses. J Agric Food Chem, 55:7981-7994.

Servia JLC, Garcaa E H, Perez NM, Bolaaos ENA, Delgado SH, Rodriguez JCC, Langarica HRG, Guzman AMV 2016. Diversity of Common Bean (Phaseolus vulgaris L.) Landraces and the Nutritional Value of Their Grains. Chapter 1 http://dx.doi.org/10.5772/63439.

Salcedo JM 2008. Regeneration Guidelines: Common Bean. In: Dull ME, Thormann I, Jorge MA, Hanson J, editors. Crop Specific Regeneration Guidelines (RD_ROM). CGIAR System-Wide Genetic Resource Programme, Roma, Italy. ) pp.9.

Suarez-Martineza SE, Ferriz-Martineza RA, CamposVegab R, Elton-Puentea JE, Torre Carbota K, Garcia-Gascaa T 2016. Bean Seeds: Leading Nutraceutical Source for Human Health. CyTA Journal of Food, 14 (1): 131-137.

Stagnari F, Maggio A, Galieni A, Pisante M 2017. Multiple Benefits of Legumes for Agriculture Sustainability: An Overview. Chem. Biol. Technol. Agric. 4: 2.

Vakali C, Papathanasiou F, Papadopoulos I, Tamoutsidis E 2009. Prelimenary Results on a Comparative Study Evaluating Land Races of Common Bean(Phaseolus vulgaris L.) Under Organic Agriculture in a Protected Areain Greece. 2nd Scientific Conference with in the Frame Work of the 9th European Summer Academy on Organic Farming June 24 - 26, 2009, Lednicena Morave, Czech Republic.

Yeken MZ, Nadeem MA, Karaköy T, Baloch FS, Çiftçi 
V 2019. Determination of Turkish Common Bean Germplasm for Morpho-Agronomic and Mineral Variations for Breeding Perspectives in Turkey. KSU J. Agric Nat 22(Suppl 1): 38-50. 